\title{
The Influence of Poverty on Maternal Deaths in Bauchi Local Government Area, Bauchi State, North East Nigeria
}

\author{
Paul Orude \\ Department of Sociology, Faculty of Management and Social Science, Federal University, Gashua, Yobe State, Nigeria \\ DOI: https://dx.doi.org/10.47772/IJRISS.2021.5421
}

\begin{abstract}
Every year, 295,000 women die from pregnancy-related causes globally, with almost all ( 94 per cent) of these maternal deaths occurring in developing nations. The purpose of this study is to determine the factor of poverty in the High Maternal Mortality Rate (MMR) in Bauchi local government area of Bauchi State. This study used the focus group discussion instrument to generate primary data. Discussants were aware that poverty was responsible for maternal deaths in their community. It also discovered that virtually all the poverty alleviation programmes initiated by governments at all levels, both past and present, have had little or no impact on targeted groups. The implication is the alarming MMR being witnessed. The study therefore recommends re-designing, careful implementing and sustaining poverty alleviation programmes to empower people. Such policies should especially target poor women and rural populace to address poverty.
\end{abstract}

Keywords: Analysis, Health care, Maternal, Mortality, Poverty, Situational

\section{INTRODUCTION}

$\mathrm{T}$ he study of maternal mortality is pertinent in view of its global concern particularly in sub-Sahara Africa. At least 295000 women died of maternal causes in 2017 (World Health Organisation, 2019). Between 2000 and 2017, the maternal mortality ratio (MMR, number of maternal deaths per 100,000 live births) dropped by about 38 per cent worldwide, but 94 per cent of maternal deaths still occur in developing nations. One of the United Nations' Millennium Development Goals (MDGs) was to reduce maternal mortality rate by 75 percent by 2015 . This was however not achieved, and, under the Sustainable Development (SDG)s Goal 3, the target is to reduce the global maternal mortality ratio to less than 70 per 100000 live births by 2030 (WHO, 2021)

The vast majority of pregnancy-related deaths in the world still occur in poor countries including sub-Saharan Africa with little or no progress made (Alvarez et al., 2009; Wall, 1998; WHO, 2019) even as maternal conditions contribute most to differences in life expectancy between men and women in low-income countries (WHO, 2019). About 34\% maternal deaths worldwide occur in Nigeria and India alone, with the MMR of Nigeria put at 814 per 100,000 live births (WHO, 2019). Women who die at child birth are the poorest of the poor, hence most pregnant women in sub-Saharan Africa remain at risk because of the poverty. The majority of women die in poorer, rural areas, where healthcare services are often inadequate or inaccessible, and where there is a severe shortage of trained medical staff (Ford, 2018).

\section{Statement of the research problem}

According to WHO's World Health Report for 2009, one third of deaths - some 18 million people a year or 50,000 per day are due to poverty-related causes.According to the National Bureau for Statistics (2019), 40 percent of Nigerians are listed as poor, translating to 82.9 million of Nigerians living in poverty. The NBS figure indicated that Bauchi is classified as one of the poorest states in Nigeria, with rate of poverty put at 61.53. A joint report (Trends in Maternal Mortality: 1990 to 2015 by WHO, UNICEF, World Bank and United Nations Population Fund) estimates that Nigeria has approximately 58,000 maternal deaths, accounting for 19 per cent globally, while 800 women die in every 100,000 live births. (WHO, 2018).

The north-Eastern region of Nigeria has one of the highest maternal mortality rate (MMR) in Nigeria with 1,549 maternal death per 100,000 live births (Meh, et al. 2019) and Bauchi is one of the states located in North-Eastern part of the country which clearly shows the problem of high maternal deaths. Bauchi Local Government Area was purposely selected because it has one of the highest maternal mortality rates in the north east region which has consistently maintained high ratio of 7,364/100,000 live births, the highest in Nigeria (Usman et al., 2018). The State also has one of the highest poverty levels in the country put at 67 per cent in 1996 (Ogwunike, 2000), According to the 2006 Census Bauchi Local Government Area has a population of 493, 810. The male and female population is 255, 340 and 238, 470 respectively (NPC, 2006). Variables that increase the probability of being poor include rural residence, possessing no education, being a self-employed farmer, polygamy, and residence in the north geopolitical zone of the country (Anyanwu, 2010). According to the Nigeria National MPDSR Assessment Report, an Assessment of Maternal and Perinatal Death Surveillance and Response Implementation (2017) data revealed that Bauchi has an estimated population of 5, 621,000 people, with 61.53 percent of the people living in poverty (Statistica, 2021). The MPDSR Assessment report for 2016 put the maternal mortality ratio at 575 , with a total 
health facilities put at 1034 across Bauchi State. Kabo et al, (2016) in their study entitled Monitoring Maternal and New born Health Outcome in Bauchi State, found out that institutional neonatal mortality rate in Bauchi decreased from 9 to 2 deaths per 1000 live births, while the institutional maternal mortality ratio dropped from 4113 to 1317 deaths per 100000 live births. The problem of maternal mortality reflects the low social status of women in the state. According to the National Demographic Health Survey NDHS, (2018), over 60 per cent of women of reproductive age (15-49) do not have western education, while only 1,1 percent of women of reproductive age have access to newspaper, television, and radios at least once a week. Several studies have been carried out on relatedness of poverty and maternal mortality, which have established the causes of pregnancy related deaths which include hemorrhage, eclampsia and pre-eclampsia, and sepsis are the major causes of maternal death in Nigeria.

Poverty can simply be defined as a social condition that is characterised by the lack of resources necessary for basic survival or necessary to meet a certain minimum level of living standards expected for the place where one lives (Thoughco, 2019). Ogwunike (2002) defines poverty as the general state in which an individual or household is unable to meet the needs of life considered as minimum requirement for sustainable livelihood in a given society. People who lack basic things such as sufficient food, shelter and clothing to sustain a physically healthy life are said to be experiencing poverty, one-third of the world's poor experienced malnourishment and starvation; live in eastern, western and sub-Saharan Africa in countries such as Nigeria (Giddens, 2006). Poverty is often identified as a major barrier to human development (Lanre-Abass 2008).

Financial barriers have had adverse effect on health care delivery, including constituting a barrier to access amongst vulnerable group, such as poor women. "User fees were introduced in Nigeria's health care system in the 1980s, when the country was undergoing a Structural Adjustment Programme (SAP). However, the negative impact of user fees on access to health-care services in developing countries is public knowledge (Reproductive Rights and Women Advocates Research and Documentation Centre, 2008: 130). User fees constitute health risks and lead to many deaths in poor populations, where they limit the people's financial ability to access health-care services as most of the world's 1.5 billion poor are female (Reproductive Rights and Women Advocates Research and Documentation Centre, 2008). Women have less access to qualitative health care in developing countries like Nigeria, a situation that has been aggravated with the introduction of user fee (Cohen, 1994; Alubo, 1987). In contemporary Nigeria, status, power and privileges determined the kind and quality of medical care one will receive (Alubo, 1999). Poverty is a major cause of maternal mortality, as it prevents many women from getting proper and adequate medical attention due to their inability to afford good antenatal care (Lanre-Abass, 2008).
In rural Africa, the risk of a woman dying in childbirth may be as high as one in eight due to the combination of high fertility, complicated pregnancies, and poor access to health care (Alubo, 1999; Mathews, 2002). Large numbers of women are born into a cycle of deprivation in Nigeria where they remain uneducated, where they may be denied access to effective medical care when they need it (Harrison, 1985). The poor state of health infrastructures in sub-Saharan Africa have thus resulted in one of the worst maternal mortality incidences in the world (Giddens, 2006; Doyal, 1979; Wall, 1998).

Despite the numerous researches on the issue, however, no study has yet to evaluate the influence of poverty on maternal deaths in neither the state nor Bauchi local government. Hence this research seeks to study the influence of maternal mortality in Bauchilocal government area of Bauchi State by asking the following questions:

1. What is the influence of poverty on maternal deaths in Bauchi Local Government?

2. What is the nature of poverty eradication programmes on poverty in the local government area?

3. What are the challenges of addressing maternal deaths in Bauchi local government area?

\section{RESEARCH HYPOTHESIS}

1. There is a relationship between poverty and maternal health especially as it relates to high maternal mortality.

2. The level of poverty has hampered efforts to address the problem of maternal mortality in the local government

Study

Study Area

Bauchi local government is one of the 20 local government areas in Bauchi State created in 1976. The study area covers an area of 3,687km2, and located by latitudes $10^{\circ} 19^{\prime} 55^{\prime \prime} \mathrm{N}$ and $10^{\circ} 20^{\prime} 58^{\prime \prime} \mathrm{N}$ and longitudes $9^{\circ} 50^{\prime} 50^{\prime \prime} \mathrm{E}$ and $9^{\circ} 51^{\prime} 29^{\prime \prime} \mathrm{E}$ (National Population Commission of Nigeria, 2021). It is bordered with Ganjuwa by the North, Kirfi by the North East, Toro by the North West, Alkaleri by the South East and Tafawa Balewa by the South West. The 2006 National Population Census puts the population of Bauchi Local Government Area at 493, 730 people while projection for 2016 estimates Bauchi Local Government Area population at 693, 700 According to Britannica (Online, 2021), Bauchi State, in general, has 55 tribal groups with Hausa, Fulani, Gerawa, Sayawa, Jarawa, Bolewa, Karekare, Kanuri, Fa'awa, Butawa, Warjawa, Zulawa and Badawa as the main tribes, (Britainica, Online, 2021)

\section{METHODS}

A focus group approach was designed to determine the impact of poverty on maternal deaths in Bauchi local government area of Bauchi State. Focus Group is frequently used as a 
qualitative approach to gain an in-depth understanding of social issues (Nyumbia, et al, 2018). Information sources included the WHO, World Bank, UNICEF and UNDP.

This research study therefore covers the entire four districts namely Zungur, Galambi, Miri and Bauchi where FGD were conducted. The Local Government Area has 20 villages under the four districts namely; The villages are classified in four districts in the table below:

Districts and villages in Bauchi Local Government Area

\begin{tabular}{|c|c|c|c|}
\hline I. ZUNGUR & II. GALAMBI & III. MIRI & IV.BAUCHI \\
\hline 1. Yamart & 1. Kangare & 1.Dan Dango & 1.Makama \\
\hline 2. Mun & 2.Tirwin & 2.Kundum & 2.Dankade \\
\hline $\begin{array}{l}\text { 3. Liman } \\
\text { Katagum }\end{array}$ & 3.Gwaskwaram & 3.Birshi & 3.Dawaki \\
\hline 4. Mulsat & & 4.Durum & 4. Hardo \\
\hline & & & 5. Dan Amar \\
\hline & & & 6. Dan Iya \\
\hline
\end{tabular}

Source: Field survey November, 2011

For the purpose of this research, Miri, Makama, Kangare, and LimanKatagum were purposefully selected. The focus group discussion was employed in carrying out the study in these communities. The main focus was on assessing the people's knowledge and views on impact of poverty on maternal deaths in the country. The study was conducted between November 2011 and September 2012.

The questions for the FGD centred around the impact of poverty on maternal mortality; the benefits of policies on poverty as they relate to maternal health; the challenges in addressing the high maternal mortality rate in Bauchi Local Government Area; and the useful ways of monitoring, evaluating and assessing programmes that would reduce maternal mortality.

The objective of the research was to determine the impact of poverty on maternal deaths in Bauchi Local government. Subsequently, FGD sessions were held in six selected villages.

\section{Distribution of Focus Group Discussants}

\begin{tabular}{|c|c|c|c|c|}
\hline S/NO & $\begin{array}{c}\text { Name of } \\
\text { village }\end{array}$ & $\begin{array}{c}\text { Number of } \\
\text { Discussants }\end{array}$ & $\begin{array}{c}\text { Number of } \\
\text { Discussants }\end{array}$ & Total \\
\hline 1 & Makama & $\begin{array}{c}\text { Women group -7 } \\
\text { Discussants } \\
\text { (Adults) }\end{array}$ & $\begin{array}{c}\text { Men group-6 } \\
\text { Discussants } \\
\text { (youths) }\end{array}$ & 13 \\
\hline 2 & $\begin{array}{c}\text { Liman } \\
\text { Katagum }\end{array}$ & $\begin{array}{c}\text { Women Group-6 } \\
\text { Discussants } \\
\text { (Youth) }\end{array}$ & $\begin{array}{c}\text { Men Group-6 } \\
\text { Discussants } \\
\text { (Youths) }\end{array}$ & 12 \\
\hline 3 & Miri & $\begin{array}{c}\text { Men Group-7 } \\
\text { Discussants } \\
\text { (Adults) }\end{array}$ & $\begin{array}{c}\text { Women } \\
\text { Group- 7 } \\
\text { Discussants } \\
\text { (Adults) }\end{array}$ & 12 \\
\hline 4 & $\begin{array}{c}\text { Men Group-6 } \\
\text { Discussants } \\
\text { (Youth) }\end{array}$ & $\begin{array}{c}\text { Women } \\
\text { Group-6 }\end{array}$ & 12 \\
\hline
\end{tabular}

Source: Field survey November, 2011

The focus group discussants were made up of minimum of six participants who were similar in characteristics. For example, male-youth, male-adult, or female-youth, female-adult. They were recruited for the discussion through the district or village head. This was sequence to approval from the Chairman Caretaker committee Bauchi Local Government Council. The Director, Primary Health Care in the Local Government made the arrangement for the recruitment participants through the traditional rulers. There were six or seven discussants for each group. Each of them was observed and listened to by the other discussants while they made their points. The items for discussion were open-ended questions that elicited discursive response. Each focus group discussion lasted for about 45 minutes or one hour and was recorded. While the researcher served as the moderator, assistant moderators were selected for each group.

\section{Analysis}

Key people who had witnessed any stage during the process leading to death of a pregnant woman were the ones who participated in the discussion. Since it was a qualitative research the discussion sessions were recorded and analysed using the Grounded Theory approach. The goal is to discover the participants' main concern about maternal mortality and how they continually try to resolve it. The results of the method are to report a set of probability statements about the relationship between poverty and maternal deaths in Bauchi Local Government Area of Bauchi State.. The FGD explored several issues, including the impact of poverty on maternal deaths, nature of poverty eradication programmes in the communities. The purpose of using focus groups was to gather respondents' personal accounts of maternal deaths. It also tries to establish the hypothesis that such deaths are largely due to the factor of poverty. The researcher engaged assistants for the FGD arrangements. For the women discussion, a woman assistant working for Community based organization was recruited while a male assistant was also engaged for the male discussion groups. The questions were read out to the respondents in Hausa language and also discussed and their responses recorded on their behalf. The discussions were tape-recorded and later transcribed. An observer was also present to take additional notes on the sessions. Efforts were made to elicit responses from all respondents. The information obtained was coded and analysed descriptively. Attention was paid to the issues and matters that were mentioned by the majority of the respondents and capturing any unique experiences reported.

Four separate groups were held in Bauchi districts namely in Miri, Makama, Kangere and Liman Katagum. These include female adult group, male adult group, female youth groups and male youth group. Each had between eight and ten participants. 49 respondents' participated in the FGD. The arrangements for setting the group discussions were facilitated through the Director Primary Health Care of the local government. For easy organization, the four groups were 
arranged through the office of the District head of Bauchi near the palace of the Emir of Bauchi. The focus group discussion with the women from Makama was done in the district head office in Bauchi. Those of Miri and Kangare were carried out in Miri and Kangare villages respectively. The focus group discussion for Liman Katagaum was held at the General Hospital. These were informal sessions with refreshments. Efforts were made to elicit responses from all respondents on maternal deaths and causes of such deaths in the various communities using a semi-structure interview guide.

\section{RESULTS}

Respondents generally acknowledged economic disadvantage and vulnerability among the communities, commonly commenting on it in the group discussions. Their situation reinforced the reported poverty rate in Bauchi which is alarming 73 per cent, one of the highest in the country (National Bureau of Statistics, 2012).

The study showed the extent to which poverty as a major factor prevents many women from getting proper and adequate medical attention due to their inability to afford good antenatal care (Lanre-Abass, 2008)

\section{Poverty and maternal health in Bauchi Local Government} Area

Poverty in a community like Kangare manifests in socioeconomic factors including malnutrition, inability of husbands to provide transportation money for their wives to visit clinics for ante-natal; home delivery; frequent delivery; illiteracy, ignorance; delay in seeking medical attention (Abdulkarim, et al, 2008).

Unemployment rate in the state is put at 41 per cent (National Bureau of Statistics, 2012). The status of women in the area of study was relatively low, compared to their male counterparts, reflecting the reported employment rate of 19 percent for women against 87 percent for men (Mairiga, 2009).

Most of the women in the study were full time housewives who were fully dependent on their husbands for economic support. For instance, the poverty in the communities the study was carried out was reflected in one of the groups' discussions with women in Makama. Out of ten women that participated in the focus group discussion in Makama, only one had a paid job as she worked with the local government council. The other women were full time housewives. Another woman, a widow with seven children had secondary education in the Makama group. The widow worked in a community based organization and served as the assistant to the researcher in Makama during the group discussion.

One of the respondents captured the poverty situation in the community: Women here have no jobs, no business, we are not empowered. With what are we going to start? Do the women have the money? Is there money? There is no money. So that is the poverty that we are talking about.
The responding women widely associated poverty with insecurity, deprived housing conditions. Other factors associated with poverty were poor nutrition, and inability to educate one's children, crime, and delinquency and so on. Discussants viewed the high poverty as having direct effect on maternal deaths. For instance, the introduction of user fee discouraged pregnant women from accessing health facilities and the consequence of such situation. Investigation showed that many women who were pregnant could not afford it. Although the state government introduced free healthcare services for pregnant mother, the study found out that poverty hampered women's ability to use those available maternal care services.

One woman in Kangare said, as a pregnant woman if you don't have money and you find yourself in this problem, when you go to hospital you will be humiliated. See you don't have money and the hospital will not give you drugs not even panadol (analgesics) without money. Before the husband or the relative of the woman will go and look for the money, in most cases, the woman has died.

Almost all the discussants in the four groups in Makama, Kangare, Miri and Liman Katagum linked poverty to insufficient access to appropriate antenatal care and delivery services as well as to poor nutrition. Due to poverty, most women in these communities were undernourished, scarcely used quality maternal services, and delivered at home.

Poor nutrition also reportedly left women with poor quality blood to go through pregnancy and such women usually die, get sick, or suffer complications during pregnancy. Enclymsia, largely as a result of poor nutrition was widely reported as the leading cause of maternal deaths among women in the area of study.

Facilities that offered good services in communities such as Makama were often privately-run and charged exorbitant prices and beyond the reach of poor households. Where cheaper Primary Health Care facilities were located such as Liman Katagum, Miri, and Kangare, women in the remote villages in these communities found it difficult to access such facilities.

Hamza, a male discussant from Miri said that there were times in the community when a pregnant woman experienced labour in the dead of night and had to be rushed to hospital about 5 kilometres. He said there are no good roads to take her to hospital. Before we got to hospital she was at the point of death, no strength in her because she had lost so much blood. Before the nurses or doctors could attend to her, she died. Respondents reported that in some villages there were no vehicles to convey pregnant women to hospital and there were times they put women experiencing labour on donkeys or horse or even cow to ride to the hospital.

Mohammed from Liman Katagum narrated seeing a woman in labour in that mode of transportation, the pregnant women go through the rough bad roads while being taken to hospital for delivery and said in most cases the women died. Another 
respondent said many villages like Makama do not have Dispensary. Sometimes before the women reach hospital the child has died in the stomach and when there is need to carry out an operation, there won't be money to pay for the operation to be carried out on the woman and that is how they were taking the woman around looking for $\$ 40,000, \ldots 30$, 000 from people who came from the village without no money. The woman just died because no money for the operation or if they get the money it is too late and she dies anyway.

The cost of reaching quality public maternal health services located outside the communities was therefore a major hindrance to women's access to quality care. Several responding women and men also frequently fingered poverty in maternal complications and deaths of other women personally known to them. One of them, a male said, "actually, the poverty among us is high that is why you see that even when a woman is in labour there is no money for the husband to take her to hospital or get a vehicle that will take her to the hospital and she starts bleeding and by this bleeding if care is not taken before they rush her to the hospital she has lost a lot of blood and this contributes to the death of pregnant women during labour"

Another respondent concurred saying in most cases when there is bleeding before the husband rushes the wife to hospital there is no more blood in her and there is no assistance from people to donate blood and before the woman is rushed to hospital she has died" Another respondent, a male from Miri observed that sometimes a man's primary concern was focused on how to feed his family first before any other thing he may not want to shoulder another responsibility like giving his wife money for transportation to hospital for ante natal care and might be thinking of how to put food on the table for his family.

The study reinforced previous research carried out in the area on the alarming maternal deaths. In prospective study of 767 maternal deaths recorded at the State Specialist Hospital Bauchi, Bauchi state Nigeria, over a period of seven years; from 1 st January 2001 to 31 st December 2007, by Maigari and Saleh (2009), out of a total of 44,281 live deliveries that occurred at the Specialist Hospital (Now Abubakar Tafawa Balewa University Teaching Hospital), the maternal mortality ratio (MMR) was 1,732 per 100,000 live births. Six hundred and twenty-one of the deaths $(81.0 \%)$ occurred in 12,067 unbooked deliveries giving a maternal mortality ratio of 5,146 per 100,000 for unbooked mothers. This ratio is approximately eleven times that obtained in 31,614 booked live deliveries with 146 maternal deaths giving a MMR of 462 per 100,000 .

\section{DISCUSSION AND FINDINGS}

The main objective of the study was to find out the impact of poverty on maternal mortality using Bauchi Local Government Area as case study. From the data collected and analysed, it is discovered that the high level of poverty has a significant impact of the high level of maternal deaths. Responding views from focus group discussions conducted suggest that poverty policy programmes and institutions have failed to alleviate poverty in various communities.

The study discovered that attaining the goals of safe motherhood and meeting the millennium development goals was a mirage with the level of poverty which the study ascertained is more pronounced among women because of their low socio-economic status compared to men. Study discussants revealed many adverse impact of poverty on their lives, including high mortality in their communities. According to them, poverty produced adverse maternal outcomes by hindering adequate nutrition and the utilization of appropriate maternity services among women. They admitted that in the communities, poverty engenders high maternal outcomes largely by hindering pregnant women access to health facilities because such facilities are far.

\section{CONCLUSION}

This study has examined from a sociological perspective the impact of poverty on maternal mortality in a sub-Sahara African community. The findings here indicated that high maternal mortality, which has dropped in many climes, is nevertheless high in the sub-region as a result of poverty. Poverty impairs women's health and hinders human development. It highlights factors responsible for maternal deaths and draws attention on the need to review poverty alleviation policy programmes of government as they are not achieving the purpose for which they are established.

It recommends the need to empower women in the country, especially in north east, as they have lower economic status through education and sound economic ventures to boost their income. In addition to boosting community enlightenment on the adverse outcome of maternal maternity on the nation's development, practical steps to involve all stakeholders in the various communities to address rising maternal deaths should be adopted.

\section{REFERENCES}

[1] Alvarez, J. L et al,. (2009) Factors associated with maternal mortality in Sub-Saharan Africa: an ecological study

[2] Abdullahi, U et al. (2020) Geographical Analysis Of Maternal Mortality In Bauchi Town. International Journal of Scientific \& Engineering Research Volume 11, Issue 10, October-2020 82 ISSN 2229-5518

[3] Assessment of Maternal and Perinatal Death Surveillance and Response Implementation in Nigeria (2017).Nigeria National MPDSR Assessment Report.Accessed from https://www.healthynewbornnetwork.org/hnncontent/uploads/Nigeria-national-MPDSR-Assessment-reportFINAL.pdf\Retrieved May 4, 2021.

[4] Britanica (2021) Bauchi State, Nigeria.https://www.britannica.com/place/Bauchi-state-Nigeria

[5] Chukuezi, C. (2010). Socio-cultural factors associated with Maternal Mortality in Nigeria Research Journal of Social Sciences; 1 (5):22-26

[6] Cohen, M. (1994). Impact of poverty on women's health, Can Fam Physician.; 40: 949-958.http://www.ncbi.nlm.nih.gov/pmc

[7] Doyal, L. (1979). The Political Economy of Health. London: Pluto Press. 
[8] Ford, L (2018) Why do women still die giving birth? 2020 Guardian News \& Media Limited,accessed from https://www.theguardian.com/globaldevelopment/2018/sep/24/why-do- women-still-die-giving-birth

[9] Giddens, A.(2006). Sociology 5th Edition. Cambridge: Polity Press.

[10] Harrison, K (1985), Maternal Mortality, British Journal of Obstetrics and Genecology 92,Supplement 5: 100-115

[11] Harrison, A. (1997). Maternal mortality in Nigeria: the real issues. African Journal of Reproductive Health; pg 1(1):7-13.

[12] Idyorough, A (2005). Gender: Concepts and Issues in Nigeria: Aboki Publishers

[13] Jordan, B (1993). Birth in Four Cultures: A Cross Cultural Investigations of births in Yucatan, Holland, Sweden and the United States, Prospect Heights, IL: Waveland Press.

[14] Karshima, J. \&Idyorough A. (2006), Poverty Reduction and Safe Motherhood in North Central and North Eastern Nigeria: A Draft Report on poverty reduction and women and child health by Safe Motherhood (SMP0 Jos and partners.

[15] Kabo, I et al. (2016) Monitoring Maternal and Newborn Health Outcome in Bauchi State, Nigeria: An evaluation of a standardsbased quality improvement intervention, International Journal for Quality in Health Care, 28(5), 566-572. https://doi.org/10.1093/intqhe/mzw083

[16] Lanre-Abbas, B, (2008). Poverty and maternal mortality in Nigeria: towards a more viable ethics of modern medical practice. International Journal for Equity in Health,

[17] Mairiga, A. G. \&Saleh, W. (2009) Maternal Mortality in the State Specialist Hospital Bauchi, Northern Nigeria, East African Medical Journal; Vol. 86 No. 1

[18] Mathew, Z. (2002). Maternal Mortality and Poverty DFID's Resource Centre for Sexual and Reproductive Health. London: John Snow International.

[19] Multiple indicator cluster Survey (1999) and National HIV/AIDS and Reproductive Health Survey (NARHS). Federal Republic of Nigeria: Federal Ministry of Health

[20] National Bureau of Statistics, 2012.

[21] National Bureau of Statistics, 2019

[22] Nigerian Demographic Survey (NDHS), (2008).National Population Commission.

[23] National Planning Commission (2004). National Economic Empowerment and Development Strategy. Abuja

[24] National Population Census 2006, Bauchi

[25] National Population Commission of Nigeria (Web), National Bureau of Statistics (Web) 2021.

[26] Nyumba at al. (2018). The use of focus group discussion methodology: Insights from two decadesof application in conservation

[27] Ogoh, A (1999), Power, Gender and Women's Health in Nigeria, Jos Journal of Social Issues, Vol 1 No. 1, pg 64-71.

[28] Ogoh, A. (1987). Power and Privileges in Medical Care An Analysis of Medical Services in Post- Colonial Nigeria. Social Sci. Med: Vol 24, No 5, pp, 453-462

[29] Ogwumike, F. (2000). An Appraisal of Poverty Reduction Strategies in Nigeria, CBN Economic and Financial Review, Vol 39 No. 4
[30] Reproductive Rights and Women Advocates Research and Documentation Centre, 2008

[31] Rotarian Action Group for Population Growth and Sustainable Development, http://www.maternal-health.eu

[32] Savarese, J (2003) Exploring the intersections between women's health and poverty. Being A Policy Paper for Prairie Women's Health Centre of Excellence

[33] Statistica https://www.statista.com/statistics/1121438/poverty-headcountrate-in-nigeria- by-state/

[34] Taiwo, O., Olusheyi, O., Lawoyin, C., \& David, A (2007). Men's Perception of Maternal Mortality in Nigeria Journal of Public Health Policy 28, 299-318 http://www.palgrave-journals.com

[35] United Nations Children Fund (UNICEF) A strategy to reduce maternal and neonatal deaths in Nigeria, UNICEF-Devpro Resource Centre, http://www.unicef.org/devpro, retrieved November, 15, 2010.

[36] United Nations Development Programme (2008-2009) Human Development Report: MDGs in Nigeria: Current report, http://web.ng.undp.org, retrieved November 15, 2010.

[37] United Nations Funds for Population Activities studies (2003, 2006), Bauchi State

[38] United Nations Millennium Development Goals Web site. [Accessed October 2010]. http://www.un.org/millenniumgoals/

[39] United Nations Population Fund (2003), Maternal Mortality Update 2002: A Focus on Emergency Obstetric Care. New York: [Accessed , October 8, 2010].http://www.unfpa.org/upload/lib_pub_file/201_filename_m mupdate-2002.pdf.

[40] UN Statistical Database, http://unstats.un.org/unsd/default.htm

[41] Wall, L. (1998). Dead Mothers and Injured Wives: The Social Context of Maternal Morbidity and Mortality among the Hausa of Northern Nigeria.Studies in FamilyPlanning Volume 29 Number 4, pg 341-358.

[42] Women Advocates Research and Documentation Centre (2008) Broken Promises;

[43] Human Rights, Accountability, and Maternal Health. New York: Center for Reproductive Rights and Women Advocates Research and Documentation Centre.

[44] World Health Organization (2010) Childbirth in developingcountries".Maternity

Worldwide. http://www.who.int/topics/maternal_health/en/ (retrievedAugust 31, 2011)

[45] World Health Organization (2005) The World Health Report: Make Every Mother and Child Count. Geneva, Switzerland: [Accessed October8, 2010].http://www.who.int/whr/2005/whr2005_en.pdf.

[46] World Health Organisation (2019): Maternal Mortality. Accessed fromhttps://www.who.int/news-room/fact-sheets/detail/maternalmortality

[47] Usman, $\mathrm{H}$ et al (2018),. A continuing tragedy of maternal mortality in a rural referral center in Northeast Nigeria: A wake-up call http://www.tjogonline.com/article.asp?issn=01895117; year $=2018 ;$ volume $=35 ;$ issue $=1 ;$ spage $=18 ;$ epage $=24 ;$ aulast $=$ $\underline{\text { Usman }}$ 